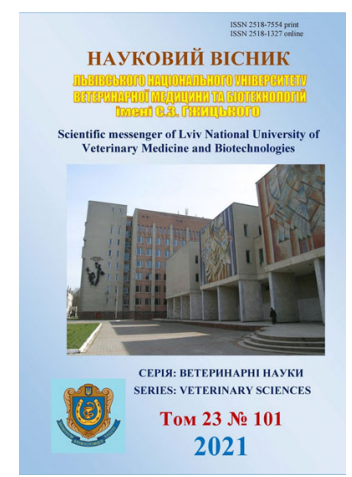

\author{
Науковий вісник Дьвівського національного університету \\ ветеринарної медицини та біотехнодогій імені С.3. Гжицького. \\ Серія: Ветеринарні науки \\ Scientific Messenger of Lviv National University \\ of Veterinary Medicine and Biotechnologies. \\ Series: Veterinary sciences
}

UDC 619: 616.071.22: 636.5-053.31

\title{
Preventive efficacy of trace elements chelates in poultry farming (review)
}

\author{
V. S. Sakara, A. Yu. Melnyk, A. V. Kharchenko \\ Bila Tserkva National Agrarian University, Bila Tserkva, Ukraine
}

Article info

Received 26.01.2021 Received in revised form 25.02 .2021 Accepted 26.02.2021

Bila Tserkva National Agrarian University, Bila Tserkva, pl. 8/1 Soborna, 09117, Ukraine. Tel.: +38-097-034-01-15 E-mail:v.sakara@outlook.com
Sakara, V. S., Melnyk, A. Yu., \& Kharchenko, A. V. (2021). Preventive efficacy of trace elements chelates in poultry farming (review). Scientific Messenger of Lviv National University of Veterinary Medicine and Biotechnologies. Series: Veterinary sciences, 23(101), 113-123. doi: $10.32718 /$ nvlvet10119

Trace elements in the body of the bird are in small quantities, but their role in productivity remains important. In order to get a quality carcass at the slaughterhouse, you need a constant supply of nutrients and, last but not least, microelements. Zinc and Manganese are essential trace elements that affect the growth and development of birds. And their deficiency in the body has a negative effect on the productivity of birds. In the diet of broilers trace elements are mainly added with a premix in the form of inorganic salts (sulfates, carbonates). However, these micronutrient compounds in the body of the bird are insufficiently absorbed, and increasing the dose of their introduction can cause toxicosis. Therefore, in order to prevent microelementosis, it is more appropriate to use organic compounds (chelates), which have a much higher level of bioavailability and less release into the environment. This review article describes the prophylactic efficacy of Zinc and Manganese chelates in micronutrient deficiencies in broiler chickens and laying hens. With a deficiency of a particular trace element develop metabolic disorders and other pathologies (perosis, etc.). Based on the presented data, it can be concluded that the use of organic forms of trace elements in poultry feeding is a better alternative to inorganic sources, as they can be used in smaller quantities. But due to their greater bioavailability, they are better absorbed, which has a positive effect on the productivity of broilers. Since knowledge about the use of chelated forms of trace elements in comparison with inorganic forms (salts, sulfates, etc.) in the diet of poultry is still poorly understood, it is necessary to further conduct research to prevent micronutrient deficiencies in these compounds.

Key words: broiler chickens, laying hens, Zinc, Manganese, chelates, microelementosis, bioavailability.

\section{Профілактична ефективність застосування хелатів мікроелементів під час вирощування сільськогосподарської птиці (огляд)}

\author{
В. С. Сакара, А. Ю. Мельник, А. В. Харченко
}

Білоиерківський національний аграрний університет, м. Біла Церква, Украӥна

\footnotetext{
Мікроелементи в тілі птииі знаходяться у невеликій кількості, але їх роль в продуктивності залишається важливою. Для того, щоб отримати на забої якісну тушку потрібне постійне надходження поживних речовин та не в останній мірі мікроелементів. Цинк та манган відносяться до ессенціальних мікроелементів, які впливають на ріст та розвиток птиці. А дефіцит їх в організмі негативно відображається на продуктивності птиці. В рачіон бройлерів мікроелементи в основному додають з преміксом у вигляді неорганічних солей (сульфатів, карбонатів). Проте, иі сполуки мікроелементів в організмі птиці засвоюються недостатньо, а підвищення дози їх введення може викликати токсикоз. Тому, з метою профілактики полімікроелементозів доиільніше застосовувати органічні сполуки (хелати), в яких значно вищий рівень біодоступності та менше виділення в навколишнє середовище. В даній оглядовій статті описана профілактична ефективність застосування хелатів иинку та мангану за дефіциту мікроелементів у курчат-бройлерів та курей несучок. Мікроелементи є важливими складовими в рачіоні курчат-бройлерів та курейнесучок. За дефіциту того чи іншого мікроелементу розвиваються порушення обміну речовин та інші патології (пероз і т.д.). На основі представлених даних можна зробити висновок, що використання органічних форм мікроелементів у годівлі птиці є кращою альтернативою неорганічним джерелам, оскільки їх можна використовувати в меншій кількості. Та через свою більшу біодосту-
} 
пність вони краще засвоюються, що позитивно впливає на продуктивність бройлерів. Оскільки знання про використання хелатних форм мікроелементів у порівнянні з неорганічними формами (солями, сульфатами і т.д.) в раціоні птиці все ще мало вивчені, необхідно подальше проводити дослідження в напрямку профілактики дефіциту мікроелементів даними сполуками.

Ключові слова: курчати-бройлери, кури-несучки, Цинк, Манган, хелати, мікроелементози, біодоступність.

\section{Вступ}

Головною умовою, яка забезпечує інтенсивність обміну речовин, є достатнє і збалансоване потрапляння в організм будівельного матеріалу, що включає як органічні так і неорганічні речовини (VillagómezEstrada et al., 2020).

Частка останніх в тілі птиці відносно невелика, але ïx роль і значення в будівництві і функціонуванні живого організму важко переоцінити. Починаючи 3 моменту виводу і до забою птиці потрібне постійне надходження мінеральних речовин 3 кормом. Як відомо, мікроелементи (Ферум, Купрум, Цинк, Манган, Кобальт, Йод, Селен і інші) належать до біоактиваторів життя (Podobed, 2017). Вони є життєво важливими речовинами, що входять до складу гормонів, ферментів, вітамінів та білково-мінеральних комплексів. Та мають великий вплив на процеси обміну білків, жирів, вуглеводів, мінеральних речовин і цим самим регулюють ріст і розвиток організму птиці, сприяючи збільшенню продуктивності і життєздатності (Vorobel' \& Pivtorak, 2011; Slivins'ka \& Fedorovich, 2012; Gaziev et al., 2013; Urdzik, 2013).

Мінеральні речовини беруть участь у побудові мікро- і макроструктур (в утворенні кісткової тканини, побудові клітинних мембран), у регулюванні осмотичного тиску в біологічних рідинах, у підтриманні кислотно-лужної рівноваги, реакції середовища (pH) на певному рівні завдяки участі їх в утворенні буферних систем біологічних рідин і тканин. Вони впливають на проникність клітинних мембран і судин, виконують важливі функції у створенні стійкості біологічних колоїдних систем. Мінеральні елементи входять до складу білків ( $\mathrm{Se}, \mathrm{S})$, коферментів (P, Co), гормонів $(\mathrm{Zn})$, беруть діяльну участь у різних ланках метаболізму (Ca, P, S, Mn, Mg). Вони активують ряд ферментних систем і можуть входити до складу активного центра ( $\mathrm{Zn}, \mathrm{Cu}, \mathrm{Ni}, \mathrm{Mo}, \mathrm{Fe})$, регулюють активність симбіотичної мікрофлори шлунково-кишкового тракту (Vorobel' \& Pivtorak, 2011).

\section{Результати та їх обговорення}

Цинк - хімічний елемент, із незамінних мікроелементів, який посідає друге місце після Феруму за розповсюдженням в організмі тварин та участю в метаболічних процесах (Red'ka et al., 2018). Основна частина Цинку у тварин знаходиться в м'язах, скелеті, шкірі та печінці. На частку інших органів приходиться 15-20 \% від загальної його кількості (Medveds'kij et al., 2016). Середня його кількість в організмі птиці складає 27 мг/кг маси тіла (Shackih, 2008).

У клітинах Цинк, здебільшого, присутній у складі стійких біокомплексів, у яких він координаційно міцно зв'язаний 3 ендогенними органічними лігандами. Це зумовлюється високою здатністю мікроелемента утворювати хелатні структури (Salami et al., 2016). Останні, як відомо, утворюються в тих випадках, коли метал розташований між атомами-донорами електронів, якими найчастіше $\epsilon$ атоми нітрогену, кисню та сульфуру. Утворенням таких сполук опосередковується роль Цинку в функціонуванні різних біологічних систем (Antonjak et al., 2011).

Цинк є компонентом близько 300 ферментів (дегідрогенази, пептидигідрази, естерази та інші) та виконує функцію їх активатора (лецитинази, аргінази, деяких пептидаз) (Park et al., 2004; Prasad et al., 2009). В організмі Цинк виконує структурну і каталітичну функції, стабілізує структуру ряду макромолекул. Так як і вітамін Е, він відіграє певну роль в функціонуванні кліткових мембран і підтримці їх цілісності та впливає на відтворювальну функцію. Також приймає участь у регулюванні засвоєння вітаміну А і Е та впливає на активність кальцію і Купруму в організмі птиці (Okolelova, 2017).

Вітамін А має вплив на виведення та на абсорбцію Цинку (Kaya et al., 2001). Він збільшує накопичення та транспортування Цинку в слизовій оболонці клубової кістки та стимулює його всмоктування. Так само на абсорбцію, транспортування та виведення вітаміну А впливає стан Цинку (Kaya et al., 2002). Його засвоєння здійснюється специфічним білкомносієм, який називається Цинк-зв'язуючим білком із вітаміном А, який $є$ високоспецифічним для іонів Цинку. Будучи необхідним для нормальної мобілізації вітаміну А з печінки в плазму, Цинк підтримує нормальні концентрації вітаміну А в крові (Kucuk et al., 2003)

Окислювальний стрес, як відомо, є важливим чинником, що сприяє виникненню хронічних захворювань (Konieczka et al., 2015). Поєднання вітаміну Е та Цинку є більш ефективним в забезпеченні стабільності корму та захисту імунної системи птиці тим самим покращуючи продуктивність (Sahin et al., 2009; Hosseini-Mansoub et al., 2010). Цинк також впливає на вуглеводний та ліпідний обмін, стимулюючи транспорт глюкози та гліколіз, також має позитивну кореляцію з концентрацією холестерину в сироватці крові (Sridhar et al., 2015).

Цей мікроелемент посилює вплив на мінералізацію, формування та збільшення маси кісток та синтез білків кератину і колагену, що утворюють пір'яний покрив (Dobrzanski et al., 2008). Він безпосередньо активує синтез аміноацил-тРНА в клітинах остеобластів та клітинного білка. Крім того, Цинк деактивує резорбцію кісткової тканини через інгібування остеокластів 3 клітин кісткового мозку (Abd El-Hack et al., 2017).

Цинк бере участь у функції піридоксалькинази, який фосфорилюєтся піридоксаль 3 утворенням піридоксаль-5-фосфату в присутності цинку $\left(\mathrm{Zn}^{2}+\right)$ і АТФ 
в печінці, піридоксаль-5-фосфат потім вивільняється в кровотік в поєднанні з альбуміном (Kucuk et al., 2008).

Цей елемент впливає на метаболізм вуглеводів і ліпідів шляхом стимулювання транспорту глюкози (Sridhar \& Foods, 2017). В передкладковий період концентрація Цинку різко підвищується в 1,51,7 разів (Podobed, 2017).

В організмі птиці засвоюється не більше 7-15\% Цинку з корму. Всмоктується він в дванадцятипалій і верхньому відділі тонкої кишки, а екскреція проходить в основному з послідом (Podobed, 2017). Високий рівень протеїну, лактози, лізину, цистеїну, гліцину, гістидину, аскорбінової і лимонної кислот підвищує засвоєння Цинку, а низький рівень протеїну, енергії та велика кількість в кормі клітковини, фітатів, Кальцію, Фосфору, Купруму, Феруму, Свинцю навпаки інгібують його абсорбцію. Кальцій, Магній та Цинк в кислому середовищі тонкої кишки утворюють міцний нерозчинний комплекс 3 фітиновою кислотою, 3 якого катіони не всмоктуються (Petrosjan, 2010; Brooks et al., 2013).

Виведення Цинку відбувається переважно за допомогою панкреатичної залози і послідом. При регуляції виведенні, затримка Цинку в організмі тісно пов'язана з його поглинанням (Jackson, 1994). Антагоністом Цинку являється Купрум (Bakulin, 2015).

Нестача Цинку надає депресивний вплив на функцію тимуса, знижує активність системи комплементу, обумовлює інактивацію іiї компонентів і обмежує формування стабільних комплексів комплементів. При його нестачі в організмі гальмується синтез ДНК, знижується активність тимідикінази і ДНК-полімерази, погіршується клітинний імунітет (Bakulin, 2015; Kwiecień et al., 2017). Дефіцит Цинку призводить до зниження Т- і Влімфоцитів, які грають основну роль в адаптивній імунній реакції. Також при взаємозв'язку з дефіцитом Купруму посилюються симптоми паракератозу (Podobed, 2017).

При дефіциті Цинку в раціоні курей-несучок (420 мг/кг корму) знижується їх продуктивність, зменшується товщина шкаралупи яєць, знижується його вміст в жовтку, погіршується виводимість курчат. При інкубації яєць, отриманих від курей 3 хронічною цинковою недостатністю, спостерігаються ембріональні каліцтва - аномалії скелета (Medveds'kij et al., 2016).

Норма введення в корм Цинку для птиці згідно рекомендацій NRC (National Research Council) складає 40 мг/кг (Brooks et al., 2013). Норми Цинку для племінних несучок становлять 65-80 мг/кг, а для промислових це показник зменшують до 40-60 мг/кг. Для індичат цей мікроелемент вводять в кількості 70 мг/кг, а для індичок-несучок - 75 мг/кг комбікорму (Podobed, 2017). Токсичний ефект Цинку не проявляється при згодовуванні курчатам 8001200 мг/кг корму, але проявлявся при дачі 1500 мг/кг і вище (Soboleva, 2017).

Для оцінки ефективності різних органічних форм Цинку у птиці, потрібно провести аналіз їх відносної біодоступності по відношенню до стандартних, неор- ганічних форм, наприклад, сульфатів мікроелементів. Результати більшості експериментів, виконаних в останні роки, продемонстрували високу відносну біодоступність органічних джерел мікроелементів. Зокрема вплив сульфату Цинку порівнювався 3 його органічною формою Availa-Zn за вмістом цього мікроелементу в великогомілковій кістці курчатбройлерів віком до 21 дня. В результатах досліджень спостерігалося, що органічний Цинк мав на $64 \%$ більшу біодоступність, ніж в формі сульфату (Star et al., 2012).

Kamran Azad S. з співавторами у 2018 р., описували, що після застосування Zn-метіонату рівень Цинку у великогомілкової кістці був відносно вищий 241,2 мг/Г в порівнянні з рівнем 228,9 мг/г після згодовування Zn-сульфату (Kamran Azad et al., 2018).

Yalcinkaya I. (2012 p.) не спостерігала суттєвого впливу органічного Zn (80 мг/кг Bio-Plex®) на показники росту та більшість біохімічних показників крові, але одночасне додавання органічного Цинку і пробіотиків (MOS) підвищувало рівень вмісту Купруму та Феруму в сироватці крові, що як стверджують автори, може вказувати на синергетичний, позитивний вплив органічних форм Цинку та пробіотиків на засвоєння мікроелементів (Yalçinkaya et al., 2012).

Ibrahim D. et al. повідомили про успішну заміну неорганічних джерел Цинку на Zn-метіонін та нано$\mathrm{Zn}$, за якої спостерігали вищі показники росту, активності антиоксидантних ферментів та накопичення цього мікроелементу (Ibrahim et al., 2017).

Feng J. та співавтори (2010 р.) описують, що додавання високих рівнів Цинку гліцину 90-120 мг/кг до раціону сприяло росту та імунологічним характеристикам концентрації IgA, IgG та IgM у крові, однак, не було різниці між групами, що отримували раціон, доповнений тим же рівнем 120 мг/кг Цинк сульфатом (Feng et al., 2010).

Kwiecień M. та співавтори (2017 р.) стверджують, що додавання Zn-Gly збільшило (P < 0,05) концентрації Купруму та Цинку в печінці бройлерів. А додавання 100, 50 і 25 мг Zn-Gly зменшило концентрацію Цинку в їх посліді у порівнянні з групою де використовували Цинк оксид. Також Zn-Gly в дозі 50 мг/кг корму збільшив концентрацію Купруму та Кальцію в сироватці крові бройлерів (Kwiecień et al., 2017).

Дослідження Refaie Amira (2009 р.) стверджують, що курчата, яких годували кормом з додаванням органічного Цинку (Biozinc) на рівні 120, 80 або 40 мг/кг, значно підвищувався вміст загального протеїну та глобулінів в крові у порівнянні з усіма іншими групами, які отримували звичайний раціон без добавок (Refaie, 2009).

Brooks M. A. et al. у 2013 році описує про позитивний ефект додавання Цинку-пропіонату в раціон, що містить знижені його рівні ( $<22$ мг $\mathrm{Zn} /$ кг раціону), а саме збільшення споживання корму, маси тіла та концентрацію Цинку в великогомілкової кістки (Brooks et al., 2013). Bahakaim A. et al. (2014) показали, що додавання Цинку в органічній формі значно підвищує концентрацію цього мікроелементу в плазмі, що мож- 
на пояснити кращою доступністю Zn-Met (Bahakaim et al., 2014).

Шевченко Л. В. та спів. у 2014 р. дослідили, що найкраще засвоєння Цинку відбувається із хелатів лізинату і гліцинату. Заміна неорганічної сполуки Цинку на комплексні сполуки 3 амінокислотами в комбікормах для курчат-бройлерів забезпечує потребу та підвищує ефективність його засвоєння (Shevchenko et al., 2014).

Одним із важливих мікроелементів у життєдіяльності птиці є Манган. Його фізіологічна роль в організмі птиці надзвичайно різноманітна. Разом із Ферумом, Купрумом та Кобальтом цей елемент впливає на процеси кровотворення. Крім того, він активує фермент фосфатазу, яка впливає на формування кістяка та загалом на стан кісткової тканини (Sakara et al., 2020).

Необхідний цей елемент для обміну аскорбінової кислоти та вітамінів групи В. Манган впливає на процеси статевого розвитку та розмноження. Манган пришвидшує утворення антитіл і спроможний стимулювати рівною мірою реакцію антиген-антитіло in vitro (Bampidis et al., 2020). За його браку в раціоні зменшується концентрація зв'язаних із холестерином ліпопротеїдів низької густини у крові, внаслідок чого виникає жирова інфільтрація печінки та посилене відкладання жиру (Klicenko, 2016).

Манган (Mn) є важливим мікроелементом, який присутній у всіх тканинах і $є$ основним для нормального метаболізму амінокислот, ліпідів, білків і вуглеводів (Zhu \& Richards, 2017). Манган діє як активатор або кофактор для різноманітних металоферментів, наприклад, мітохондріальної супероксиддисмутази, яка $є$ одним із найважливіших ферментів антиоксидантного захисту, аргінази, що каталізує розщеплення аргініну до орнітину і сечовини в печінці, піруваткарбоксилази - життєво важливого ферменту глюконеогенезу, глутамінсинтетази, яка перетворює глутамат у глутамін (Yatoo et al., 2013). Ферментам, яким потрібен Манган, також є гідролази, оксидоредуктази, ліази, ізомерази, лігази і трансферази (Petrinich et al., 2017).

Манган бере участь у функції численних систем органів (Ognik et al., 2019). Він необхідний для нормальної імунної функції, регуляції цукру в крові і клітинної енергії, відтворення, травлення, росту кісток, а також допомагає захисним механізмам проти вільних радикалів. Спільно з вітаміном К підтримує згортання крові і гемостаз (Aschner \& Aschner, 2005), a iз Ферумом, Купрумом та Кобальтом цей елемент впливає на процеси кровотворення. У малих кількостях активує окисні процеси. Також, сприяє синтезу вітаміну С в організмі, пов'язаний з синтезом $\mathrm{B}_{6}$, та функцією вітамінів Е і A (Shackih, 2013).

Манган необхідний для утворення кісток, оскільки впливає на ферментативну активність глікозилтрансферази. Серед них, галактозилтрансфераза необхідна для мукополісахаридів, які мають важливу роль у синтезі хряща матриці (Liu et al., 2015). Бере участь у синтезі глюкопротеїдів та стимулює дію гормонів передньої частки гіпофізу (Klicenko, 2016).
Всмоктування його проходить в основному в дванадцятипалій кишці. Абсорбція його 3 кормом дуже низька - в середньому 2-5 \% від прийнятої кількості (Levchenko, 2015). Надходячи до жовчі, Манган екскретується з організму переважно з послідом (Tufarelli \& Laudadio, 2017), а певна його кількість підшлунковою залозою, яка у випадку холестазу може навіть стати основним органом його виділення. Але при надлишковому надходженні він елімінується через стінку кишечника, в першу чергу через проксимальний відділ клубової кишки (Kucan et al., 2014).

На величину всмоктування впливають рівень Кальцію, Натрію і Феруму в раціоні (Zhabykpaeva et al., 2017). На зниження рівня Mn в органах впливає дефіцит вітаміну $\mathrm{B}_{1}$, та надлишок кальцію в раціоні. Певною мірою проявляє синергічну дію по відношенню до вітаміну $\mathrm{B}_{4}-$ холіну, та попереджає жирове переродження печінки (Zhabykpaeva et al., 2017). За браку Мангану в раціоні зменшується концентрація зв'язаних із холестерином ліпопротеїдів низької густини у крові, внаслідок чого виникає жирова інфільтрація печінки та посилене відкладання жиру (Klicenko, 2016).

Рекомендована норма вводу Мангану 60 мг/кг корму, згідно рекомендацій NRC (National Research Council) (Jackson, 1994). Lu et.al описує, що в країнах Азії в промисловому вирощуванні курчат-бройлерів використовують Манган в дозі 120 мг/кг корму (Lu et al., 2006). Sunder G. S. et al. описує, що доповнення Мангану на рівні 100 мг/кг до основного раціону покращую мінералізацію кісток і зменшує випадки розвитку перозу і $\epsilon$ оптимальним рівнем для курчатбройлерів. Більш його високі рівні до 800 мг/кг не мають ніякого позитивного ефекту. Збільшення додавання Мангану до 1600 або 3200 мг/кг негативно впливає на прирости, конверсію корму, засвоювання Кальцію, Фосфору та Цинку, на кісткову та імунну компетентність (Sunder et al., 2006). Експерименти Li et al. показали, що оптимальний рівень Мангану для бройлерів віком 1-21 діб, становить близько 130 мг/кг корму (Li et al., 2011).

Нестача його в організмі викликає захворювання пероз, при якому сильно збільшений скакальний суглоб, скручений чи загнутий нижній кінець великогомілкової кістки і верхній кінець плюсни. При нестачі мангану знижується яйценосність, погіршується якість шкарлупи і стан оперення, знижуються відтворювальні якості (заплідненість яєць і вивід курчат). Ембріони гинуть на 20-21 день інкубації. На розтині відмічають ознаки хондродистрофії - ноги вкорочені, дзьоб викривлений (папуги). У вилуплених курчат інколи відмічають атаксію, підвищену збудливість в наступному проявляється ознаки перозу. Критерієм забезпеченості манганом $є$ його концентрація в печінці, нирках та кістковій тканині (Okolelova, 2017). Всмоктування його проходить в основному в дванадцятипалій кишці. Абсорбція його з кормом дуже низька - в середньому 2$5 \%$ від прийнятої кількості (Levchenko et al., 2015). Insko et al. описував в своїй статті про те, що мінімум 30 мг/кг Mn, доповненого до основного раціону (що містить 7 мг Mn/кг), необхідно для профілактики перо- 
зу. Дослідження показали, що при застосуванні $\mathrm{Mn}$ неможливо повністю уникнути слабкості кінцівок. Gallup та Norris повідомили, що коли рівень Mn в раціоні збільшується до $50 \mathrm{мг/кг,} \mathrm{захворюваність} \mathrm{птиці}$ перозом знижується приблизно на 4 \%, проте повна профілактика неможлива навіть тоді, коли рівень Мn в раціоні збільшений до 500 і 1000 мг/кг (Li et al., 2011). NRC CША рекомендує бройлерам у віці 1-42 денного віку вводити манган у раціон в кількості 60 мг/кг корму (Lu et al., 2016).

Аналіз тканин Е. Berta та співавтори у своїх дослідженнях показали, що великогомілкова кістка мала найбільш показову реакцію на Манган потім печінка та нирки. Накопичення у великогомілкової кістки було вище $(\mathrm{P}<0,05)$ з добавками 30, 60 і 240 мг/кг 3 обох джерел $\mathrm{Mn}(3,71$ 3,78, 4,44, мг/кг MnO i 3,68, 4,00, 4,36 мг/кг Мn фумарату). відповідно) порівняно 3 контрольною групою (3,21 мг/кг) курчат-бройлерів 7 тижневого віку (Berta et al., 2004).

Shyam Sunder та інші дослідники у 2013 році дослідили, що при додаванні органічного Мангану 60 мг/кг в корм суттєво збільшується засвоєння Цинку (Р < 0,01) (Sunder et al., 2013). Взаємодія органічних Цинку та Мангану при 80 і 60 мг/кг, відповідно, підтримувала їх вміст (Р < 0,01) у тканинах печінки. Відповідно, комбінація органічного Цинку та Мангану при 80 : 60 мг/кг була синергічною для посилення мінералізації кісткової тканини, поглинання мінералів тканинами і імунної відповіді у курчат-бройлерів у віці 35 днів. А комбінація органічних Цинку та Мангану при 160 : 60 мг/кг відповідно забезпечила високу концентрацію Цинку (271 мг/кг) у гомілковій кістці (Sunder et al., 2013).

Sunder G. S. (2006) показав, що добавляння Мангану в кількості 100 мг/кг оптимізує показники продуктивності, мінералізації та імунну відповідь у курчат-бройлерів (Sunder et al., 2006). Органічно пов'язані мікроелементи, такі як гліцин хелати (Е.С.О. Тrace®), характеризуються високою біодоступністю, за його застосування рівень Мангану значно виріс у великогомілковій кістці порівняно з сульфатами та контрольною групою (Landver, 2018).

Біодоступність мікроелементів в формі хелатних сполук з гідрокси-аналогом метіоніна (MINTREX®) вище, ніж неорганічних солей. У наукових дослідженнях і промислових випробуваннях при введенні в раціон Цинку, Купруму та Мангану у вигляді хелатів відмічалося поліпшення стану кісткової та сполучної тканин птиці (Burdone, 2015).

Багато останніх досліджень птиці спрямовані на оцінку ефективності комбінації мікроелементів, що додаються одночасно, в органічних формах, до раціону (Świątkiewicz et al., 2014). Zhao J. et al. (2010 p.) у 2 проведених дослідах на бройлерах спостерігали, що продуктивність та здоров'я кінцівок, покращилися під час годівлі 50 : 50 суміші неорганічних (сульфатів) і хелатних форм Цинку, Купруму і Мангану. Птахи, які отримували суміш мікроелементів, демонстрували подібні або поліпшені показники росту і краще зберігання мікроелементів у тканинах порівняно з контро- льною групою, яка отримувала тільки неорганічні мікроелементи (Zhao et al., 2010).

За введення до раціонів курчат-бройлерів незначних кількостей (30 мл суміші з рівних частин) наноаквахелатів $\mathrm{Ag}, \mathrm{Cu}, \mathrm{Zn}, \mathrm{Mg}$, Со відзначено позитивний вплив на еритропоез за одночасного зниження кількості лейкоцитів, що, на думку авторів, зумовлено певною санацією кишкової мікрофлори в зв'язку з вираженою бактерицидною дією, і в першу чергу, Срібла (Medvid et al., 2017).

Проведені дослідження Симонова Г. (2010 р.) дозволили зробити висновок, що застосування в раціоні курчат-бройлерів цитратів мікроелементів підвищує збереженість на 2,0-6,0 \% середньодобовий приріст на 2,9-7,5 \%, живу масу на 2,8-7,5 \% (Simonov, 2010). Згодовування цитратів мікроелементів замість неорганічних сполук Феруму, Кобальту, Мангану та Цинку сприяє збільшенню маси тушки на 6,6-9,7 \%. Найбільш позитивно на зростання, розвиток і збереження птиці впливають цитрати мікроелементів при включенні їх до складу раціону в таких кількостях: Ферум 0,045 г, Манган 0,09 г, Цинк 0,072 г, Кобальт 0,00075 г на 1 кг корму (Fedin et al., 2012).

Органічні мінеральні джерела представляються цінними альтернативами для заміни неорганічних джерел. Що дозволяє знизити на 50 \% мінеральні добавки (Cu 5 мг/кг, Fe 15 мг/кг, Zn 40 мг/кг, Mn 50 мг/кг) у раціоні, тим самим значно знижуючи вміст мікроелементів в екскрементах (De Marco et al., 2017).

Lopes M. et al. (2018 p.) описує, що використання органічних джерел мікроелементів (Zn, Mn i Se) у раціонах курчат-бройлерів збільшує їх концентрацію в крові та печінці, але без змін у складі кісток порівняно 3 годівлею 3 неорганічними формами. Корми, сформовані з 50 \% органічних і 50 \% неорганічних мінералів, дають подібні результати (Lopes et al., 2018).

Mondal S. et al. у 2010 році провели дослідження по впливу білкових хелатів (protein chelates) обмін речовин в курчат-бройлерів. У групі де додавалися білкові хелати патології кінцівок не спостерігалися, тоді як у контрольної захворюваність склала 16 \% (Mondal et al., 2010).

Дослідник Khillare G. та ін. (2019 р) описують, що якщо концентрація Мангану в раціоні 270 мг/кг може покращити склад біохімічних компонентів в плазмі, мінеральний статус, імунну відповідь, фертильність і виводимість в бройлерних самцях на більш пізньому етапі періоду виробництва (Khillare et al., 2019). Концентрація мікроелементів ( $\mathrm{Cu}, \mathrm{Fe}, \mathrm{Mn}, \mathrm{Zn})$ у сироватці, печінці та м'язових зразках була вищою $(\mathrm{P}<0,05)$ у групах де додавали хелати, що вказувало на збільшення засвоєння зазначених мінеральних елементів внаслідок добавок (Mondal et al., 2010).

Слід також зазначити за властивість амінокислот (гліцину та лізину) які є основою (або клешнями) для мікроелементів при виробництві хелатів. Манган в органічній формі має вищу ефективність, ніж неорганічний (Mn-сульфат), а ліганд метіоніну краще сприяє абсорбції Мангану ніж гліцин (Olgun, 2017).

Амінокислота лізин, що входить в склад лізинатів, сприяє збільшенню засвоєння білка (Chang et al., 
2018). Тому вона могла сприяти збільшенню живої маси та концентрації загального протеїну, після застосування лізинатів Мангану. Wang В. (2016 р.) у своїх дослідженнях описав, про ефективність використання пантотенової кислоти на прирости живої маси та обмін речовин (Wang et al., 2016).

Застосування Zn-Gly покращилася якість великогомілкової кістки і стегнової кістки і їх параметри міцності, можливо, через збільшеного осадження Са і Р в кістках (Kwiecień et al., 2016). Зниження добавки Цинку в раціоні на 50 \% (20 ppm) з заміною його на Цинк гліцинат мав такі самі результати як при застосуванні $100 \%$ (40 ppm) добавок 3 неорганічного джерела (Sridhar \& Foods, 2015).

Купрум $(\mathrm{Cu})$ це мікроелемент, що має багато фізіологічних функцій у тварин та птиці, включаючи скелетну мінералізацію, еритропоез, лейкопоез, синтез сполучної тканини, формування мієліну, синтез пігменту меланіну, метаболізм катехоламіну, термічна регуляція, імунна функція, та регуляція метаболізму глюкози. Відомо, що Купрум бере участь у метаболізмі кісток як важливий кофактор, необхідний для

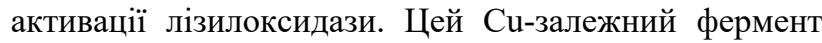
ініціює критичний процес формування ковалентного перехресного зв'язку в еластині та колагені в кістках та інших сполучних тканинах. Також дослідження по введенню до раціону додатково Купруму свідчать про те, що його дефіцит призводить до втрати кісткової тканини (остеопенія або остеопороз) (Kim et al., 2016; Muszyński et al., 2017).

Одна з найважливіших функцій Купруму - участь в процесах кровотворення. Під його впливом прискорюється утворення гемоглобіну. Він сприяє дозріванню еритроцитів на ранніх стадіях розвитку, збільшенню їх кількості і розміру, переходу мінеральних форм Феруму в органічні, посилює мобілізацію депонованого Феруму і перенесення його до кісткового мозку (Vorobel' \& Pivtorak, 2011).

Ферум - це хімічний елемент, що має декілька життєво важливих функцій в організмі. Це важливий мікроелемент для росту бройлерів, який бере участь у численних енергетичних метаболічних процесах, синтезі нейротрансміттерів та фагоцитній антимікробній активності, а також у синтезі ДНК, колагену та жовчних кислот. Найбільша частка феруму в тілі, 60 70 \%, пов'язана з гемоглобіном у крові, 10 \% є компонентом міоглобіну та ферментів, включаючи каталази, пероксидази, оксидази, цитохроми, РНКдегідрогенази, беручи участь у фундаментальних процесах обміну речовин (Shinde et al., 2011; Kwiecień et al., 2015; Xinyan et al., 2016; Akter et al., 2017).

Селен (Se) є невід'ємним мікроелементом для птиці, який відіграє важливу роль у функціонуванні антиоксидантів, метаболізмі тиреоїдного гормону, репродукції та імунної регресії. Додавання дієт з сільськогосподарськими тваринами стимулюється благотворним впливом цього елемента на здоров'я тварин та поліпшенням якості харчових продуктів тваринного походження (Fagan et al., 2015; Surai \& Fisinin, 2014). Селен є складовою частиною одного з провідних ферментів антирадикального захисту організму - глутатіонпероксидази, біологічна роль якої - надавати захисну дію проти окисного стресу, каталізувати розпад перекису водню. Крім того, мікроелемент бере участь в обміні жиророзчинних вітамінів А, E, а також у синтезі коензиму Q (каталізатора енергетичних процесів на клітинному рівні); має захисні властивості при отруєнні курей солями важких металів, токсинами. Що ж стосується імуномодулюючої дії селену, то вона зачіпає як гуморальні, так і клітинні ланки імунної системи (Musich, 2015).

Проте мікроелементи часто або зовсім ігноруються, або їм виділяється недостатньо уваги (2011). Низький рівень есенційних мікроелементів спричиняє виникнення відповідних мікроелементозів, які здебільшого, мають субклінічний перебіг і рідше проявляються типовими ознаками, що ускладнює ранню діагностику хвороби. При цьому в організмі птиці відбуваються значні порушення метаболізму на молекулярному рівні (Koltun \& Katins'kij, 2011). Традиційно мікроелементи вводять у раціони птиці у вигляді неорганічних сполук металів (оксидів, сульфатів, карбонатів, хлоридів), що значною мірою обумовлене дешевизною цього виду сировини. Але у шлунковокишковому тракті ці солі розпадаються на вільні високо реактивні іони, які починають взаємодіяти один із одним і різними компонентами раціонів, що робить їх важкодоступними для абсорбції. Наприклад, Ферум, Манган і Кобальт конкурують між собою у процесі всмоктування, а кальцій, сірка, фітинова кислота та інші компоненти корму утворюють із вільними іонами мікроелементів нерозчинні або погано розчинні сполуки, які не засвоюються у кишечнику. Крім того, солі мікроелементів, особливо сірчанокислі і солянокислі, при змішуванні з вітамінами, прискорюють руйнування останніх (Saprkin et al., 2016).

Відомо, що найкращою формою мікроелементів для організму птиці $є$ хелатні сполуки елементів 3 амінокислотами, білками тощо. Хелати це натуральні або синтетичні внутрішньокомплексні сполуки, які перетворюють мікроелементи на доступну для засвоєння форму, утримуючи їх всередині хелатного кільця (Nishhemenko et al., 2014). Мікроелементи у такому випадку знаходяться у захищеній формі, не відбуваються явища антагонізму металів, і до того ж, амінокислотні ліганди надають хелатам здатності легше проходити крізь мембрани клітин, щоб безпосередньо залучатися до процесів обміну речовин (Marchenkov \& Storozhuk, 2010).

На раціонах з амінокислотними хелатами виділення мікроелементів із випорожненнями птиці у зовнішнє середовище у кілька разів менше, ніж при використанні звичайних, неорганічних джерел мікроелементів. Це має позитивний вплив на екологічний стан птахівничих ферм і $є$ особливо актуальним питанням у країнах $\mathrm{CC}$, де діють жорсткі обмеження на викиди мікроелементів у зовнішнє середовище (Marchenkov et al., 2009). Серед амінокислотних хелатів найбільш ефективними є гліцинати та лізинати мікроелементів, а менш дієвими являються метіонати. Це пов'язано 3 низькою токсичністю, вищою доступністю для організму, відсутністю негативних побічних ефектів, сти- 
муляції метаболічних процесів та високою біологічною активністю хелатних сполук мікроелементів в організмі птиці (Shevchenko et al., 2017).

Мікроелементи (Fe, $\mathrm{Zn}, \mathrm{Co}, \mathrm{Cu}, \mathrm{Mn}$ ) у наноцитратній формі, за рахунок кращої біодоступності та біоактивності справляють свій позитивний вплив на формування і становлення факторів неспецифічної резистентності та клітинний імунітет в курчат-бройлерів у дозі, що відповідає 25-50 \% від обгрунтованої кількості біоелементів у стандартному мінеральному преміксі (Medvid, 2018).

Одне 3 найважливіших способів оцінки ефективності різних джерел мікроелементів у птиці провести аналіз їх відносної біодоступності по відношенню до стандартних, неорганічних форм, наприклад, сульфатів мікроелементів. Результати більшості експериментів, виконаних в останні роки, продемонстрували високу відносну біодоступність органічних джерел мікроелементів. Зокрема вплив сульфату цинку порівнювався $з$ органічним цинком Availa-Zn за його вмістом у великогомілковій кістці курчат-бройлерів віком до 21 дня. В результаті досліджень спостерігалося, що органічний цинк мав на 64 \% більшу біодоступність, ніж сульфат цинку (Star et al., 2012). Рівень цинку у великогомілковій кістці після застосування Zn-метіоніну був відносно вищий 241,2 мг/Г в порівнянні 3 рівнем 228,9 мГ/Г після згодовування Znсульфату (Kamran Azad et al., 2018).

Yalcinkaya I. та співавтори (2012 р.) не спостерігали вплив органічного Zn (80 мг/кг Bio-Plex®) на показники росту та більшість біохімічних показників крові, але одночасне додавання органічного Zn i пробіотиків (MOS) підвищувало рівень вмісту $\mathrm{Cu}$ та $\mathrm{Fe}$ в сироватці крові, що як стверджують автори, може вказувати на синергетичний, позитивний вплив органічних Zn i MOS на засвоєння мікроелементів (Yalçinkaya et al., 2012). Додавання високих рівнів Zn гліцину 90-120 мг/кг до раціону сприяло росту та імунологічним характеристикам концентрації $\operatorname{IgA}$, IgG та IgM у крові, однак, не було різниці між групами, що отримували раціон, доповнений тим же рівнем 120 мг/кг Zn гліцином та неорганічним Zn сульфатом (Feng et al., 2010). Додавання до раціону курчатбройлерів органічного преміксу сприяло збільшені концентрації $\mathrm{Cu}, \mathrm{Mn}$ та $\mathrm{Zn}$ у сироватці крові в порівнянні 3 контрольною та групою де застосовувався неорганічний премікс (Mondal et al., 2010).

Додавання Zn-Gly збільшило (P < 0,05) концентраціï $\mathrm{Cu}$ i Zn у печінці бройлерів, а додавання 100, 50 i 25 мг Zn-Gly зменшило концентрацію цинку в їх посліді у порівнянні з групою де використовували цинк оксид. Також Zn-Gly в дозі 50 мг/кг корму збільшив концентрацію $\mathrm{Cu}$ і Са у сироватці крові бройлерів (Kwiecień et al., 2017). Дослідження Amira стверджують, що курчата, яких годували кормом $з$ додаванням органічного цинку (Biozinc) на рівні 120, 80 або 40 мг/кг, значно підвищував вміст загального білка та глобулінів в крові у порівнянні з усіма іншими групами (Refaie, 2009).

Біодоступність Мn-пропіонату в порівнянні 3 сировиною Mn сульфату, вища виходячи з результатів дослідження концентрації Mn в кістці (Brooks et al., 2013). Органічні Zn та Mn в дозах 80 та 60 мг/кг корму виражали синергізм для підвищення мінеральної біодоступності та імунної відповіді у курчатбройлерів до 35 денного віку. Комбінація органічних $\mathrm{Zn}$ i Mn при 160:60 мг/кг відповідно забезпечила високу концентрацію Zn (271 мг/кг) у гомілковій кістці (Sunder et al., 2013).

Багато останніх досліджень 3 птиці спрямовані на оцінку ефективності комбінації мікроелементів, що додаються одночасно, в органічних формах, до раціону (Świątkiewicz et al., 2014). За введення до раціонів курчат-бройлерів незначних кількостей (30 мл суміші 3 рівних частин) наноаквахелатів $\mathrm{Ag}, \mathrm{Cu}, \mathrm{Zn}, \mathrm{Mg}$, Co відзначено позитивний вплив на еритропоез за одночасного зниження кількості лейкоцитів, що, на думку авторів, зумовлено певною санацією кишкової мікрофлори в зв'язку з вираженою бактерицидною дією, і в першу чергу, срібла (Medvid et al., 2017).

\section{Висновки}

Мікроелементи є важливими складовими в раціоні курчат-бройлерів та курей-несучок. За дефіциту того чи іншого мікроелементу розвиваються порушення обміну речовин та інші патології (пероз і т.д.). На основі представлених даних можна зробити висновок, що використання органічних форм мікроелементів у годівлі птиці $є$ кращою альтернативою неорганічним джерелам, оскільки їх можна використовувати в меншій кількості. Та через свою більшу біодоступність вони краще засвоюються, що позитивно впливає на продуктивність бройлерів. Оскільки знання про використання хелатних форм мікроелементів у порівнянні 3 неорганічними формами (солями, сульфатами і т.д.) в раціоні птиці все ще мало вивчені, необхідно подальше проводити дослідження в напрямку профілактики дефіциту мікроелементів даними сполуками.

\section{References}

Abd El-Hack, M. E., Alagawany, M., Arif, M., Chaudhry, M. T., Emam, M., \& Patra, A. (2017). Organic or inorganic Zinc in poultry nutrition: a review. World's Poultry Science Journal, 73(4), 904-915. doi: 10.1017/S0043933917000769.

Akter, M., Iji, P. A., \& Graham, H. (2017). Increased iron level in phytase-supplemented diets reduces performance and nutrient utilisation in broiler chickens. British Poultry Science, 58(4), 409-417. doi: 10.1080/00071668.2017.1315050.

Antonjak, G. L., Vazhnenko, O. V., Bovt, V. D., \& Stefanishin, O. M. (2011). Biologichna rol' Cinku v organizmi ljudini i tvarin. Biologija Tvarin, 13(1-2), 17-31 (in Ukrainian).

Aschner, J. L., \& Aschner, M. (2005). Nutritional aspects of Manganese homeostasis. Molecular Aspects of Medicine, 26(4-5), 353-362. doi: 10.1016/j.mam.2005.07.003.

Bahakaim, A., Magied, H. A., Osman, S., Omar, A., AbdelMalak, N. Y., \& Ramadan, N. (2014). Effect of using different levels and sources of Zinc in layer's 
diets on egg Zinc enrichment. Egyptian Poultry Science, 34(1), 39-56. doi: 10.21608/epsj.2014.5305.

Bakulin, V. A. (2015). Nedostatok makro- i mikrojelementov. Efektivne Ptahivnictvo, 9(129), 16-19 (in Ukrainian).

Bampidis, V., Azimonti, G., Bastos, M. de L., Christensen, H., Dusemund, B., Kos Durjava, M., \& Ramos, F. (2020). Safety and efficacy of Manganese chelates of lysine and glutamic acid as feed additive for all animal species. EFSA Journal, 18(2). doi: 10.2903/j.efsa.2020.6001.

Berta, E., Andrásofszky, E., Bersényi, A., Glávits, R., Gáspárdy, A., \& Fekete, S. G. (2004). Effect of inorganic and organic Manganese supplementation on the performance and tissue Manganese content of broiler chicks. Acta Veterinaria Hungarica, 52(2), 199-209. doi: 10.1556/AVet.52.2004.2.8.

Brooks, M. A., Grimes, J. L., Lloyd, K. E., Verissimo, S., \& Spears, J. W. (2013). Bioavailability in chicks of Zinc from Zinc propionate. The Journal of Applied Poultry Research, 22(2), 153-159. doi: 10.3382/japr.2012-00525.

Burdone, A. (2015). Melaty mikrojelementov: uspeshnyj otkorm i pererabotka. Zhivotnovodstvo Rossii, 6, 3840 (in Russian).

Chang, L. ling, Xie, P., Bu, Z., Wang, Q., Fu, S., \& Mu, C. (2018). Effect of dietary lysine level on performance, egg quality and serum biochemical indices of laying pigeons. Journal of Applied Poultry Research, 27(2), 152-158. doi: 10.3382/japr/pfx047.

De Marco, M., Zoon, M. V., Margetyal, C., Picart, C., \& Ionescu, C. (2017). Dietary administration of glycine complexed trace minerals can improve performance and slaughter yield in broilers and reduces mineral excretion. Animal Feed Science and Technology, 232, 182-189. doi: 10.1016/j.anifeedsci.2017.08.016.

Dobrzanski, Z., Korczynski, M., Chojnacka, K., Gorecki, H., \& Opalinski, S. (2008). Influence of Organic Forms of Copper, Manganese and Iron on Bioaccumulation of These Metals and Zinc in Laying Hens. Journal of Elementology, 13(3), 309-319. URL: http://www.uwm.edu.pl/jold/poj1332008/jurnal-03.pdf.

Fagan, S., Owens, R., Ward, P., Connolly, C., Doyle, S., \& Murphy, R. (2015). Biochemical comparison of commercial Selenium yeast preparations. Biological Trace Element Research, 166(2), 245-259. doi: 10.1007/s12011-015-0242-6.

Fedin, A., Gajirbegov, D., Simonov, G., \& Denisov, D. (2012). Kremnij organicheskaja dobavka $\mathrm{v}$ racionah nesushek. Pticevodstvo, 5, 33-34 (in Russian).

Feng, J., Ma, W. Q., Niu, H. H., Wu, X. M., Wang, Y., \& Feng, J. (2010). Effects of Zinc Glycine Chelate on Growth, Hematological, and Immunological Characteristics in Broilers. Biological Trace Element Research, 133(2), 203-211. doi: 10.1007/s12011-009-8431-9.

Gaziev, B. M., Saprkin, V. O., Ionov, I. A., Zhukors'kij, O. M., Marchenkoov, F. S., \& Martenjuk, I. O. (2013). Efektyvnist' zgodovuvannja riznyh doz helatnoi formy zaliza suporosnym i laktujuchym svynomatkam. Visnyk AgrarnoiNauky, 2, 26-30 (in Ukrainian).

Hosseini-Mansoub, N., Chekani-Azar, S., Tehrani, A., Lotfi, A., \& Manesh, M. (2010). Influence of dietary vitamin $\mathrm{E}$ and Zinc on performance, oxidative stability and some blood measures of broiler chickens reared under heat stress $\left(35^{\circ} \mathrm{C}\right)$. Journal of Agrobiology, 27(2), 103-110. doi: 10.2478/s10146-009-0012-1.

Ibrahim, D., Ali, H., \& El-Mandrawy, S. (2017). Effects of Different Zinc Sources on Performance, Bio Distribution of Minerals and Expression of Genes Related to Metabolism of Broiler Chickens. Zagazig Veterinary Journal, 45(3), 292-304. doi: 10.21608/zvjz.2017.7954.

Jackson, J. B. C. (1994). Nutrient Requirements of Poultry: Ninth Revised Edition. doi: 10.1073/pnas.091092898.

Kamran Azad, S., Shariatmadari, F., Karimi Torshizi, M. A., \& Ahmadi, H. (2018). Effect of zinc concentration and source on performance, tissue mineral status, activity of superoxide dismutase enzyme and lipid peroxidation of meat in broiler chickens. Animal Production Science, 58(10), 1837. doi: 10.1071/AN15758.

Kaya, Ş., Keçeci, T., \& Haliloğlu, S. (2001). Effects of Zinc and vitamin A supplements on plasma levels of thyroid hormones, cholesterol, glucose and egg yolk cholesterol of laying hens. Research in Veterinary Science, 71(2), 135-139. doi: 10.1053/rvsc.2001.0500.

Kaya, S., Ortatatli, M., \& Haliloglu, S. (2002). Feeding diets supplemented with Zinc and vitamin A in laying hens: effects on histopathological findings and tissue mineral contents. Research in Veterinary Science, 73(3), 251-257. doi: 10.1016/S0034-5288(02)00095-4.

Khillare, G. S., Shyamkumar, T. S., Ahmad, M., Prabhakar, G., Rokade, J. J., Beulah, P. V., Gopi, M. (2019). Effects of dietary Manganese supplementation on selected biochemical characteristics and minerals in broiler breeder seminal plasma. Indian Journal of Poultry Science, 54(1), 37. doi: 10.5958/0974-8180.2019.00011.4.

Kim, J. W., Kim, J. H., Shin, J. E., \& Kil, D. Y. (2016). Relative bioavailability of Copper in tribasic copper chloride to Copper in Copper sulfate for laying hens based on egg yolk and feather Copper concentrations. Poultry Science, 95(7), 1591-1597. doi: 10.3382/ps/pew049.

Klicenko, T. G. (2016). Vplyv mineral'nyh elementiv na peretravnist' i zasvoiennia rechovyn u ptyci. Efektivne Ptahivnyctvo, 3(135), 16-18 (in Ukrainian).

Koltun, E. M., \& Katins'kij, Ju. M. (2011). Profilaktika i diagnostyka mikroelementoziv cynku, jodu u kurchat brojleriv. Naukovyi Visnyk LNUVMBT imeni S. Z. Gzhyc'kogo, 13(4(50)), 92-99 (in Ukrainian).

Konieczka, P., Czauderna, M., \& Smulikowska, S. (2015). The effect of dietary fat, vitamin E and selenium concentrations on the fatty acid profile and oxidative stability of frozen stored broiler meat. Jornal of Animal and Feed Sciences, 24(September), 244-251. doi: $10.22358 /$ jafs $/ 65630 / 2015$.

Kucan, O. T., Orobchenko, O. L., \& Kochergin, Ju. A. (2014). Toksyko-biohimichna harakterystyka neorganichnyh elementiv ta zastosuvannja rentgenofluorescentnogo analizu u veterinarnij medycyni (Planetapr). Harkiv (in Ukrainian).

Kucuk, O., Kahraman, A., Kurt, I., Yildiz, N., \& Onmaz, A. C. (2008). A Combination of Zinc and Pyridoxine Supplementation to the Diet of Laying Hens Improves Performance and Egg Quality. Biological Trace Element Research, 126(1-3), 165-175. doi: 10.1007/s12011-0088190-z. 
Kucuk, O., Sahin, N., \& Sahin, K. (2003). Supplemental Zinc and vitamin A can alleviate negative effects of heat stress in broiler chickens. Biological Trace Element Research, 94(3), 225-235. doi: 10.1385/BTER:94:3:225.

Kwiecień, M., Samolińska, W., \& Bujanowicz-Haraś, B. (2015). Effects of iron-glycine chelate on growth, carcass characteristic, liver mineral concentrations and haematological and biochemical blood parameters in broilers. Journal of Animal Physiology and Animal Nutrition, 99(6), 1184-1196. doi: 10.1111/jpn.12322.

Kwiecień, M., Winiarska-Mieczan, A., Milczarek, A., \& Klebaniuk, R. (2017). Biological Response of Broiler Chickens to Decreasing Dietary Inclusion Levels of Zinc Glycine Chelate. Biological Trace Element Research, 175(1), 204-213. doi: 10.1007/s12011-016-0743-y.

Kwiecień, M., Winiarska-Mieczan, A., Milczarek, A., Tomaszewska, E., \& Matras, J. (2016). Effects of Zinc glycine chelate on growth performance, carcass characteristics, bone quality, and mineral content in bone of broiler chicken. Livestock Science, 191, 43-50. doi: 10.1016/j.livsci.2016.07.005.

Landver, B. (2018). Optimizacija potrebnosti v mikrojelementah s pomoshh'ju glicinatov. Zhivotnovodstvo Rossii, 2, 14-16 (in Russian).

Levchenko, V. I., Vlizlo, V. V., \& Kondrahin, I. P. (2015). Vnutrishni hvoroby tvaryn. Bila Cerkva (in Ukrainian).

Li, S., Lin, Y., Lu, L., Xi, L., Wang, Z., Hao, S., Luo, X. (2011). An Estimation of the Manganese Requirement for Broilers from 1 to 21 Days of Age. Biological Trace Element Research, 143(2), 939-948. doi: 10.1007/s12011-010-8931-7.

Liu, R., Jin, C., Wang, Z., Wang, Z., Wang, J., \& Wang, L. (2015). Effects of Manganese deficiency on the microstructure of proximal tibia and OPG/RANKL gene expression in chicks. Veterinary Research Communications, 39(1), 31-37. doi: 10.1007/s11259-015-9626-5.

Lopes, M., Paroul, N., Barbosa, J., Valduga, E., Cansian, R. L., Toniazzo, G., \& Oliveira, D. (2018). Effect of Partial and Total Replacement of Inorganic by Organic Microminerals Sources on the Quality of Broiler Carcasses. Brazilian Archives of Biology and Technology, 60, 1-11. doi: 10.1590/1678-4324-2017160082.

Lu, L., Chang, B., Liao, X., Wang, R., Zhang, L., \& Luo, X. (2016). Use of molecular biomarkers to estimate manganese requirements for broiler chickens from 22 to $42 \mathrm{~d}$ of age. British Journal of Nutrition, 116(09), 1512-1518. doi: 10.1017/S0007114516003640.

Lu, L., Ji, C., Luo, X. G., Liu, B., \& Yu, S. X. (2006). The effect of supplemental Manganese in broiler diets on abdominal fat deposition and meat quality. Animal Feed Science and Technology, 129(1-2), 49-59. doi: 10.1016/j.anifeedsci.2005.12.005.

Marchenkov, F. S., \& Storozhuk, T. V. (2010). Helatni mikroelementy - vazhlivyi komponent kombikormiv ta premiksiv. Zernovi Produkti i Kombikormy, 1, 3738 (in Ukrainian).

Marchenkov, F., Martinjuk, I., \& Vashhenko, O. (2009). Helatni mikroelementy $\mathrm{v}$ godivli ptyci. Nashe Ptahivnictvo, 6, 26-27 (in Ukrainian).

Medveds'kij, V. A., Bazylev, M. V., Bol'shakova, L. P., \&
Munajar, H. F. (2016). Biologicheskie osnovy mineral'nogo pitanija sel'skohozjajstvennoj pticy. Nauchnoe obozrenie. biologicheskie nauki, 2, 93-108 (in Russian).

Medvid, S. (2018). Effect of aquacitrate of micro elements on indices of nonspecific resistance and cellular immunity in chicken broilers. Scientific Messenger of LNU of Veterinary Medicine and Biotechnologies. Series: Agricultural Sciences, 20(84), 33-38. doi: 10.15421/nvlvet8406.

Medvid, S. M., Hunchak, A. V., Gutyj, B. V., \& Ratych, I. B. (2017). Prospects of rational security chickenbroilers with mineral substances. Scientific Messenger of LNU of Veterinary Medicine and Biotechnologies, 19(79), 127-134. doi: 10.15421/nvlvet7925.

Mikoni, N. A., Poppenga, R., Ackerman, J. T., Foley, J., Hazlehurst, J., Purdin, G., \& Tell, L. A. (2017). Trace element contamination in feather and tissue samples from Anna's hummingbirds. Ecological Indicators, 80, 96-105. doi: 10.1016/j.ecolind.2017.04.053.

Mondal, S., Haldar, S., Saha, P., \& Ghosh, T. K. (2010). Metabolism and Tissue Distribution of Trace Elements in Broiler Chickens' Fed Diets Containing Deficient and Plethoric Levels of Copper, Manganese, and Zinc. Biological Trace Element Research, 137(2), 190-205. doi: 10.1007/s12011-009-8570-z.

Muszyński, S., Tomaszewska, E., Kwiecień, M., Dobrowolski, P., \& Tomczyk, A. (2017). Effect of Dietary Phytase Supplementation on Bone and Hyaline Cartilage Development of Broilers Fed with Organically Complexed Copper in a Cu-Deficient Diet. Biological Trace Element Research, 1-15. doi: 10.1007/s12011-017-1092-1.

Musich, O. I. (2015). Produktivnist' kurej za riznyh doz organichnogo selenu. Naukovo-Tehnichnyi Bjuleten' IT NAAN, 114, 98-103 (in Ukrainian).

Nishhemenko, M. P., Emel'janenko, A. A., \& Stovbec'ka, L. S. (2014). Harakterystyka embrional'nogo rozvytku, vyvodu i vyvodymosti molodnjaku perepeliv pry inkubacijnij obrobci jaec' rozchynom akvahelatu Selenu. Visnyk Sums'kogo Nacional'nogo Agrarnogo Universitetu Serija "Veterinarna Medicina”, 1(34), 77-80 (in Ukrainian).

Ognik, K., Kozłowski, K., Steępniowska, A., Szlaęzak, R., Tutaj, K., Zduńczyk, Z., \& Jankowski, J. (2019). The effect of manganese nanoparticles on performance, redox reactions and epigenetic changes in Turkey tissues. Animal, 13(6), 1137-1144. doi: $10.1017 /$ S1751731118002653.

Okolelova, T. M. (2017). Makro- i mikrojelementy v kormlenii pticy. Efektivne Ptahivnictvo, 3(147), 2630 (in Russian).

Olgun, O. (2017). Manganese in poultry nutrition and its effect on performance and eggshell quality. World's Poultry Science Journal, 73(01), 45-56. doi: 10.1017/S0043933916000891.

Park, S. Y., Birkhold, S. G., Kubena, L. F., Nisbet, D. J., \& Ricke, S. C. (2004). Review on the role of dietary Zinc in poultry nutrition, immunity, and reproduction. Biological Trace Element Research, 101(2), 147-163. doi: 10.1385/BTER:101:2:147.

Petrinich, V. V., \& Petrinich, O. A. (2017). Marganec': toksykologichni, gigienichni ta biologichni aspekty. 
Klinichna ta Eksperimental'na Patologija, 1(59), 182184 (in Ukrainian).

Petrosjan, A. B. (2010). Priroda biodostupnosti mikrojelementov. Ptica i Ptice Produkty, 1, 35-38 (in Russian).

Podobed, L. I. (2017). Mikrojelementy Ferrum i Cink znachenie i normirovanie v kormlenii pticy. Suchasne Ptahivnictvo, 01-02(170-171), 35-37 (in Russian).

Prasad, A. S., Beck, F. W. J., Snell, D. C., \& Kucuk, O. (2009). Zinc in cancer prevention. Nutrition and Cancer, 61(6), 879-887. doi: 10.1080/01635580903285122.

Red'ka, A. I., Bomko, V. S., Babenko, S. P., \& Chernyavsky, A. A. (2018). Broiler Chickens Biochemical Blood Indicators By the Zinc Sulfate and Zinc-Mixed Ligand Complex Feeding. The Scientific and Technical Bulletin of the Institute of Animal Science NAAS of Ukraine, 120, 127-135. doi: 10.32900/2312-8402-2018-120-127-135.

Refaie, A. (2009). Performance and Immunocompetence of Broilers As Affected By Dietary Zinc, Protein Level and Phytase Supplementation During Performance and Immunocompetence of Broilers As Affected By Dietary Zinc, Protein Level and Phytase Supplementation During Summer. 5th International Poultry Conference (10-13 March 2009), 959-981.

Sahin, K., Sahin, N., Kucuk, O., Hayirli, A., \& Prasad, A. S. (2009). Role of dietary zinc in heat-stressed poultry: A review. Poultry Science, 88(10), 2176-2183. doi: 10.3382/ps.2008-00560.

Sakara, V. S., Melnyk, A. Y., Sakhniuk, V. V., Bakhur, T. I., Bohatko, L. M., \& Samorai, M. M. (2020). Changes in protein and mineral metabolism in broiler chickens with perosis. Regulatory Mechanisms in Biosystems, 11(4), 542-545. doi: 10.15421/022083.

Salami, S. A., Oluwatosin, O. O., Oso, A. O., Fafiolu, A. O., Sogunle, O. M., Jegede, A. V., \& Pirgozliev, V. (2016). Bioavailability of $\mathrm{Cu}, \mathrm{Zn}$ and $\mathrm{Mn}$ from Mineral Chelates or Blends of Inorganic Salts in Growing Turkeys Fed with Supplemental Riboflavin and/or Pyridoxine. Biological Trace Element Research, 173(1), 168-176. doi: 10.1007/s12011-016-0618-2.

Saprkin, V. O., Ionov, I. A., Gaziev, B. M., Zhukors'kij, O. M., \& Marchenkov, F. S. (2016). Helatni formy zaliza u godivli suporosnyh ta laktujuchyh svynomatok. Biologija ta Ekologija, 2(2), 70-79 (in Ukrainian).

Shackih, E. V. (2008). Kachestvo m'jasa brojlerov pri ispol'zovanii biopleksa cinka. Ptica i Pticeprodukty, 3, 36-37 (in Ukrainian).

Shackih, E. V. (2013). Ispol'zovanie biopleksa Marganca v kormlenii cypljat-brojlerov. Agrarnyj Vestnik Urala, 3(109), 33-35 (in Russian).

Shevchenko, L. V., Jaremchuk, O. S., Gusak, S. V., Mihal's'ka, V. M., \& Poljakovs'kij, V. M. (2017). Vmist mikroelementiv ta vitaminu A v jajcjah pereppeliv za vplyvu kompleksu glicynativ mirokelementiv ta mikrobnogo $\beta$-karotynu. Ukrainan Jornal of Ecology, 7(2), 19-23. doi: 10.15421/201716 (in Ukrainian).

Shevchenko, L. V., Mihal's'ka, V. M., Maljuga, L. V., \& Poljakovs'kij, V. M. (2014). Kompleksni spoluky mikroelementiv - suchasni zasoby profilaktyky hvorob ptyci. Bioresursi i Prirodokoristovannja, 6(12), 67-70 (in Ukrainian).
Shinde, P. L., Ingale, S. L., Choi, J. Y., Kim, J. S., Pak, S. I., \& Chae, B. J. (2011). Efficiency of inorganic and organic Iron sources under iron depleted conditions in broilers. British Poultry Science, 52(5), 578-583. doi: 10.1080/00071668.2011.607430.

Simonov, G. (2010). Cytraty biomaterialov v racionah cipljat-brojlerov. Pticevodstvo, 1, 42-43 (in Ukrainian).

Slivins'ka, L. G., \& Fedorovich, N. (2012). Zastosuvannja helatnyh spoluk mikroelementiv u molodnjaku ovec'. Naukovyi Visnyk LNUVMBT imeni S. Z. Gzhyc'kogo, 14(3(53)), 252-257 (in Ukrainian).

Soboleva, A. A. (2017). Toksicheskie dozy Cinka v racione kur-nesushek. Aktual'nye Voprosy Nezaraznoj Patologii Zhivotnyh: Materialy I Mezhdunarodnoj Nauchno-Prakticheskoj Studencheskoj Konferencii. 31 Marta 2017 G., (1), 204-206. URL: http://lib.ugsha.ru:8080/handle/123456789/12582 (in Russian).

Sridhar, K., \& Foods, S. (2017). Effect of graded concentration of organic zinc (Zn-glycinate ) on skin quality, haematological and serum biochemical constituents in broiler chicks Effect of graded concentration of organic zinc (zinc glycinate) on skin quality, hematological and ser

Sridhar, K., Nagalakshmi, D., \& Rama Rao, S. V. (2015). Effect of graded concentration of organic zinc (zinc glycinate) on skin quality, hematological and serum biochemical constituents in broiler chicken. Indian Journal of Animal Sciences, 85(6), 643-648.

Star, L., van der Klis, J. D., Rapp, C., \& Ward, T. L. (2012). Bioavailability of organic and inorganic zinc sources in male broilers. Poultry Science, 91(12), 3115-3120. doi: 10.3382/ps.2012-02314.

Şule, K., Umucalilar, H. D., Haliloğlu, S., \& Ipek, H. (2001). Effect of Dietary Vitamin A and Zinc on Egg Yield and Some Blood Parameters of Laying Hens. Turkish Journal of Veterinary and Animal Sciences, 25(5), 763-769.

Sunder, G. S., Kumar, C. V., Panda, A. K., Raju, M. V. L. N., \& Rao, S. V. R. (2013). Effect of Supplemental Organic $\mathrm{Zn}$ and $\mathrm{Mn}$ on Broiler Performance, Bone Measures, Tissue Mineral Uptake and Immune Response at 35 Days of Age. Current Research in Poultry Science, 3(1), 1-11. doi: 10.3923/crpsaj.2013.1.11.

Sunder, G. S., Panda, A. K., Gopinath, N. C. S., Raju, M. V. L. N., Rao, S. V. R., \& Kumar, C. V. (2006). Effect of Supplemental Manganese on Mineral Uptake by Tissues and Immune Response in Broiler Chickens. The Journal of Poultry Science, 43(4), 371-377. doi: $10.2141 /$ jpsa.43.371.

Surai, P. F., \& Fisinin, V. I. (2014). Selenium in poultry breeder nutrition: An update. Animal Feed Science and Technology, 191, 1-15. doi: 10.1016/j.anifeedsci.2014.02.005.

Świątkiewicz, S., Arczewska-Włosek, A., \& Józefiak, D. (2014). The efficacy of organic minerals in poultry nutrition: review and implications of recent studies. World's Poultry Science Journal, 70(03), 475-486. doi: 10.1017/S0043933914000531.

Tufarelli, V., \& Laudadio, V. (2017). Manganese and its role in poultry nutrition: an overview. Journal of Experimental Biology and Agricultural Sciences, 5(6), 
749-754. doi: 10.18006/2017.5(6).749.754.

Urdzik, R. M. (2013). Problemy nestachi mineraliv u ptahivnyctvi: projavi, naslidky ta shljahi vyrishennja. Efektivne Ptahivnictvo, 10(106), 38-40 (in Ukrainian).

Villagómez-Estrada, S., Pérez, J. F., van Kuijk, S., MeloDurán, D., Karimirad, R., \& Solà-Oriol, D. (2020). Effects of two Zinc supplementation levels and two Zinc and Copper sources with different solubility characteristics on the growth performance, carcass characteristics and digestibility of growing-finishing pigs. Journal of Animal Physiology and Animal Nutrition, (August), 1-13. doi: 10.1111/jpn.13447.

Vorobel', M. I., \& Pivtorak, Ja. I. (2011). Znachennja mikroelementiv u zhittedijal'nosti tvaryn. Naukovyi Visnyk LNUVMBT imeni S.Z. Gzhyc'kogo, 13(3(50)), 54-60 (in Ukrainian).

Wang, B., Zhang, X., Yue, B., Ge, W., Zhang, M., Ma, C., \& Kong, M. (2016). Effects of pantothenic acid on growth performance, slaughter performance, lipid metabolism, and antioxidant function of Wulong geese aged one to four weeks. Animal Nutrition, 2(4), 312 317. doi: 10.1016/j.aninu.2016.07.005.

Xinyan, M., Xiudong, L., Lin, L., Sufen, L., Liyang, Z., \& Xugang, L. (2016). Determination of Dietary Iron Requirements by Full Expression of Iron-Containing Enzymes in Various Tissues of Broilers 1-3. The Journal of

Nutrition,

(5),

2267-2273. doi: 10.3945/jn.116.237750.participate.

Yalçinkaya, I., Çinar, M., Yildirim, E., Erat, S., Başalan, M., \& Güngör, T. (2012). The effect of prebiotic and organic zinc alone and in combination in broiler diets on the performance and some blood parameters. Italian Journal of Animal Science, 11(3), e55. doi: 10.4081/ijas.2012.e55.

Yatoo, M. I., Saxena, A., Deepa, P. M., Habeab, B. P., Devi, S., Jatav, R. S., \& Dimri, U. (2013). Role of trace elements in animals: a review. Veterinary World, 6(12), 963-967. doi: 10.14202/vetworld.2013.963-967.

Zhabykpaeva, A. G., Ryshhanova, R. M., \& Ermolina, S. A. (2017). Znachenie jessenceal'nyh mikrojelementov dlja zhiznedejatel'nosti ptic. Mnogoprofil'nij Nauchnij Zhurnal "Intellekt, Ideja, Innovacija", 2, 27-35 (in Russian).

Zhao, J., Shirley, R. B., Vazquez-Anon, M., Dibner, J. J., Richards, J. D., Fisher, P., ... Giesen, A. F. (2010). Effects of chelated trace minerals on growth performance, breast meat yield, and footpad health in commercial meat broilers. The Journal of Applied Poultry Research, 19(4), 365-372. doi: 10.3382/japr.2009-00020.

Zhu, W., \& Richards, N. G. J. (2017). Biological functions controlled by manganese redox changes in mononuclear Mn-dependent enzymes. Essays in Biochemistry, 61(2), 259-270. doi: 10.1042/EBC20160070. 